\title{
Pola Pengeluaran Rumah Tangga di Kabupaten Sangihe, Talaud dan Sitaro Menggunakan Analisis Biplot
}

\section{Arini Mamangkeya*, Jantje D.Pranga, Djoni Hatidjaa}

aJurusan Matematika, FMIPA, Unsrat, Manado

\section{KA T A K U N C I}

Analisis Biplot

Pengeluaran Rumah Tangga

KEYW OR D S

Biplot Analysis

Household Expenditure

\section{AVAILABLE ONLINE} 31 Januari 2013

\begin{abstract}
A B S T R A K
Tujuan dari penelitian ini adalah untuk mengetahui karakteristik pengeluaran dominan dari pola pengeluaran rumah tangga di Kabupaten Sangihe, Talaud dan Sitaro. Untuk mencapai tujuan tersebut, maka digunakan analisis biplot yang dapat memberi hasil dalam bentuk tampilan grafis. Analisis biplot dilakukan secara terpisah pada masingmasing Kabupaten. Data yang digunakan adalah hasil Survei Sosial Ekonomi Nasional tahun 2010 Provinsi Sulawesi Utara. Hasil analisis biplot menunjukkan peubah-peubah yang mendominasi pola pengeluaran untuk makanan di Kabupaten Sangihe, Talaud dan Sitaro adalah pengeluaran untuk mie, kerupuk, rokok, telur, susu, kacang-kacangan, daging, ikan, minuman alkohol, buah-buahan, bumbu-bumbuan, sayursayuran, ubi-ubian, minyak, lemak, bahan minuman, makanan jadi, minuman jadi, padi-padian. Sedangkan pengeluaran bukan makanan didominasi oleh biaya pendidikan, pajak, asuransi, pemeliharaan rumah , keperluan pesta, aneka barang dan jasa, barang tahan lama, pakaian dan alas kaki, serta biaya kesehatan.

A B S T R A C T

The objective of this research was to discover the dominant characteristic in household expenditure at Regency of Sangihe, Talaud and Sitaro. For accomplishing that goal, then biplot analysis is used to build a visual graphic for each data. Biplot Analysis has conducted apart for each Region. Data of this research based on SUSENAS in 2010 North Sulawesi Province. The result of this research showed variables which are dominated food expenditure at Region of Sangihe, Talaud and Sitaro. They are noodles, crackers, cigarettes, eggs, milk, legumes, meat, fish, alcohol beverages, fruits, spices, vegetables, tubers, oil, fats, beverage stuff, prepared food, prepared beverages, cereals. Non-food expenditure is dominated by education cost, taxes, insurance, housing facility, parties, goods and services, durable goods, clothing and footwear, and also healthy cost.
\end{abstract}

\section{Pendahuluan}

Daerah kepulauan merupakan wilayah dimana luas perairan lebih besar daripada luas daratan dan memiliki banyak pulau kecil terluar. Daerah kepulauan memiliki tingkat kesejahteraan masyarakat relatif lebih rendah dibandingkan dengan daerah nonkepulauan. Persentase penduduk miskin tahun 2010 untuk daerah Sangihe, Talaud dan Sitaro berturutturut sebesar $7,16 \%, 7,22 \%$ dan $8,46 \%$ sedangkan
Kota Manado persentase penduduk miskinnya sebesar 4,37\% (Anonim, 2010). Indikasi utama tingginya angka kemiskinan di daerah kepulauan adalah kebutuhan pokok rumah tangga yang sulit diperoleh. Daerah kepulauan Sangihe dan Talaud adalah daerah dengan kecamatan terbanyak yang beresiko tinggi terhadap tingkat kerawanan pangan (Anonim, 2011a). Kerawanan pangan ini dapat disebabkan pola konsumsi masyarakat yang rendah untuk makanan (Anonim, 2011c). Pengeluaran rumah 
tangga merupakan salah satu indikator yang digunakan untuk mengukur kesejahteraan rumah tangga/keluarga. Jika pengeluaran untuk makanan terhadap total pengeluaran lebih besar dibandingkan pengeluaran bukan makanan mengindikasikan rumah tangga yang berpenghasilan rendah. Semakin kecil persentase pengeluaran makanan terhadap total pengeluaran rumah tangga, maka semakin sejahtera rumah tangga tersebut (Anonim, 2011b).

Berdasarkan ulasan di atas, perlu dilakukan pengkajian terhadap pola pengeluaran rumah tangga di daerah kepulauan dengan maksud untuk mengetahui karakteristik dominan dari pola pengeluaran di daerah tersebut menggunakan analisis biplot.

Tujuan penelitian ini adalah untuk mengetahui karakteristik pola pengeluaran di daerah kepulauan dan mengidentifikasi peubah yang mendominasi karakteristik pengeluaran rumah tangga menggunakan analisis biplot.

\subsection{Studi Literatur}

\subsubsection{Pengeluaran Konsumsi Rumah Tangga}

Pengeluaran konsumsi rumah tangga mencakup berbagai pengeluaran konsumsi akhir rumah tangga atas barang dan jasa untuk memenuhi kebutuhan individu atau kelompok secara langsung. Pengeluaran rumah tangga terdiri dari pengeluaran untuk makanan dan pengeluaran bukan makanan. Pengeluaran untuk makanan adalah nilai pengeluaran untuk konsumsi rumah tangga selama seminggu yang lalu baik dari pembelian, produksi atau pemberian. Pengeluaran bukan makanan adalah nilai pengeluaran untuk konsumsi bukan makanan rumah tangga selama sebulan atau 12 bulan yang lalu (Anonim, 2011b).

\subsubsection{Analisis Biplot}

Biplot adalah gambaran dimensi ganda pada suatu matriks data $X$ yang menunjukkan setiap $n$ vektor pengamatan (baris $X$ ) dengan setiap $p$ peubah (kolom X) (Rencher, 2002). Ada 4 hal penting yang dapat dilihat dari biplot yaitu sebagai berikut:

a. Hubungan (korelasi) antar peubah, dengan menggunakan biplot peubah akan digambarkan sebagai garis berarah. Dua peubah yang memiliki korelasi positif tinggi akan digambarkan sebagai dua buah garis dengan arah yang sama, atau membentuk sudut yang sempit. Apabila dua peubah yang memiliki korelasi negatif tinggi akan digambarkan dalam bentuk dua garis yang arahnya berlawanan, atau membentuk sudut yang lebar (tumpul). Sedangkan dua buah peubah yang tidak berkorelasi akan digambarkan dalam bentuk dua garis yang mendekati $90^{\circ}$ (siku-siku)

b. Keragaman peubah, informasi ini digunakan untuk melihat apakah ada peubah tertentu yang nilainya hampir sama setiap objek ada yang sama besar dan ada juga yang sangat kecil. Dalam biplot, peubah dengan keragaman kecil digambarkan dengan vektor yang pendek, sedangkan peubah yang ragamnya besar digambarkan sebagai vektor yang panjang.

c. Kedekatan antar objek, informasi ini bisa dijadikan panduan objek mana yang memiliki kemiripan karakteristik dengan objek tertentu. Dalam biplot, dua objek dengan karakteristik sama akan digambarkan sebagai dua titik yang posisinya berdekatan.

d. Nilai peubah pada suatu objek, informasi ini digunakan untuk melihat keunggulan dari setiap objek. Objek yang terletak searah dengan arah dari suatu peubah dikatakan bahwa pada objek tersebut nilainya di atas rata-rata. Sebaliknya jika objek lain terletak berlawanan dengan arah dari peubah tersebut maka objek tersebut memiliki nilai dekat dengan rata-rata (Mattjik, et al., 2004).

Analisis biplot didasarkan pada penguraian nilainilai singular suatu matriks. Misalkan $X$ adalah matriks data dengan $n$ objek dan $\mathrm{p}$ peubah yang berpangkat $r$ yang telah dikoreksi oleh rataannya diuraikan menjadi perkalian tiga buah matriks, maka dapat dituliskan menjadi:

$$
X=U L A^{\prime}
$$

matriks $U$ dan $A$ adalah matriks berukuran $(n \times r)$ dan $(p \times r)$ sedemikian sehingga $U^{\prime} U=A^{\prime} A=I r . L$ adalah matriks diagonal berukuran $(r \times r)$ dengan elemen-elemennya adalah $\sqrt{\lambda_{1}} \geq \sqrt{\lambda_{2}} \geq \cdots \geq \sqrt{\lambda_{r}}$ ,dengan $\lambda_{\mathrm{i}}$ adalah akar ciri dari matriks $X^{\prime} X$, dan $r$ adalah pangkat matriks $X$. Unsur-unsur diagonal dari matriks $L$ disebut nilai singular matriks $X$. Secara teknis kolom-kolom matriks $U$ terdiri dari $r$ vektor ciri dari matriks $X^{\prime} X$.

Kolom-kolom matriks $A$ terdiri dari $r$ vektor ciri dari matriks $X^{\prime} X$ yang berpadanan dengan akar ciri $\lambda$. Kolom-kolom matriks $A$ disebut vektor singular baris matriks $X$ dalam ruang berdimensi $p$. Dengan penjabaran persamaan

$$
X=U L A^{\prime}=U L^{\propto} L^{1-\propto} A^{\prime}
$$

Jika didefinisikan $G=U L^{\alpha}$ dan $H=A L^{1-\alpha}$, Untuk $0 \leq$ $\alpha \leq 1$ persamaan (2) dapat ditulis:

$$
X={ }_{n} G_{r} H_{p}^{\prime}
$$

Maka unsur ke-(ij) matriks $X$ dapat ditulis sebagai

$X_{i j}=g_{i} h_{j}$,

dimana $i=1,2, \ldots, n ., j=1,2, \ldots, p$.

Jika matriks $X$ berpangkat dua $(r=2)$, maka seluruh vektor baris $g_{i}$ dan vektor kolom $h_{j}$ dapat diplotkan didalam ruang berdimensi dua. Apabila matriks $X$ berpangkat lebih dari dua $r>2$, maka dapat didekati dengan persamaan matriks berpangkat dua, sehingga persamaan (4) dapat ditulis menjadi

$$
{ }_{2} X_{i j}=g_{i} * h_{j} \text { * }
$$

Dengan ${ }_{2} X_{i j}$ merupakan matriks pendekatan matriks $X$ pada dimensi dua. Sedangkan $g_{i}$ * dan $h_{j}$ * masing-masing mengandung 2 unsur pertama vektor $g_{i}$ dan $h_{j}$, atau unsur-unsurnya terdiri dari komponen pertama dan kedua matriks $\mathrm{G}$ dan $\mathrm{H}$.

Dalam pendeskripsian biplot, ada sebuah unsur ketidakunikan nilai $\alpha$ dalam mendefinisikan matriks $\mathrm{G}$ 
dan $\mathrm{H}$. Untuk $\alpha=0$ dan $\alpha=1$ akan mempermudah interpretasi hasil dari biplot itu sendiri. Jika $\alpha=0$ maka $\mathrm{G}=\mathrm{U}$ dan $\mathrm{H}=L A^{\prime}$ sehingga diperoleh persamaan: $X^{\prime} X=\left(G H^{\prime}\right){ }^{\prime}\left(G H^{\prime}\right)=H H^{\prime}$

Karena $X^{\prime} X=H H^{\prime}=(n-1) S$, maka hasil kali $h_{j} h_{k}$, akan sama dengan (n-1) $S_{j k}$. dimana $S_{j k}$ adalah peragam dan $h_{j} h_{k}$ menggambarkan keragaman peubah ke-k, sedangkan korelasi antara peubah ke-j dan ke-k adalah nilai cosinus sudut antara vektor $h_{j}$ dan $h_{k}$ (Jollife, 1986).

Jika $\alpha=1$ maka $\mathrm{G}=\mathrm{UL}$ dan $\mathrm{H}=\mathrm{A}$, sehingga $X^{\prime} X=$ $\left(G H^{\prime}\right) \quad\left(G H^{\prime}\right)^{\prime}=G H^{\prime} H G^{\prime}=G A^{\prime} A G^{\prime}=G G^{\prime}$ Dengan demikian, jarak euclid antara $g_{h}$ dan $g_{i}$ akan sama dengan jarak euclid $x_{h}$ dan $x_{i}$.

\section{Metode}

\subsection{Data}

Data yang digunakan adalah data SUSENAS tahun 2010 dari Badan Pusat Statistik Provinsi Sulawesi Utara. Objek pengamatan adalah Kecamatan-Kecamatan di Kabupaten Sangihe, Talaud dan Sitaro.

\subsection{Peubah Penelitian}

Peubah penelitian ditunjukkan dalam Tabel 1 dan Tabel 2.

Tabel 1 - Peubah Pengeluaran untuk Makanan (X1)

\begin{tabular}{|l|l|}
\hline Kode & Nama Peubah \\
\hline $\mathrm{X} 1_{1}$ & Pengeluaran untuk padi-padian \\
\hline $\mathrm{X} 1_{2}$ & Pengeluaran untuk ubi-ubian \\
\hline $\mathrm{X} 1_{3}$ & Pengeluaran untuk ikan \\
\hline $\mathrm{X} 1_{4}$ & Pengeluaran untuk daging \\
\hline $\mathrm{X} 1_{5}$ & Pengeluaran untuk telur dan susu \\
\hline $\mathrm{X} 1_{6}$ & Pengeluaran untuk sayur-sayuran \\
\hline $\mathrm{X} 1_{7}$ & Pengeluaran untuk kacang-kacangan \\
\hline $\mathrm{X} 1_{8}$ & Pengeluaran untuk buah-buahan \\
\hline $\mathrm{X} 1_{9}$ & Pengeluaran untuk minyak dan lemak \\
\hline $\mathrm{X} 1_{10}$ & Pengeluaran untuk bahan minuman \\
\hline $\mathrm{X} 1_{11}$ & Pengeluaran untuk bumbu-bumbuan \\
\hline $\mathrm{X} 1_{12}$ & Pengeluaran untuk konsumsi lainnya \\
\hline $\mathrm{X} 1_{13}$ & $\begin{array}{l}\text { Pengeluaran untuk makanan jadi dan } \\
\text { minuman jadi }\end{array}$ \\
\hline $\mathrm{X} 1_{14}$ & Pengeluaran untuk minuman alkohol \\
\hline $\mathrm{X} 1_{15}$ & Pengeluaran untuk tembakau dan sirih \\
\hline
\end{tabular}

\subsection{Analisis Data}

Analisis data dalam penelitian ini menggunakan analisis biplot dengan langkah-langkah : 1)Pemasukan data untuk data matrix $X$, 2)Melakukan penghitungan matriks koragam/peragam $S$, 3)Pembentukan matriks diagonal yang unsurunsurnya merupakan simpangan baku, 4)Penghitungan matriks korelasi dari matriks $X$, e)Standarisasi matriks $X, 5)$ Penguraian matriks $X$ yang telah distandarisasi dengan SVD (Singular Value Decomposition), 6)Penghitungan matriks $\mathrm{H}=\mathrm{AL}$ dan $\mathrm{G}=\mathrm{UL}, 7$ )Plot matriks $\mathrm{G}$ dan $\mathrm{H}$ secara tumpang tindih.

Tabel 2 - Peubah Pengeluaran Bukan Makanan (X2)

\begin{tabular}{|l|l|}
\hline Kode & Nama Peubah \\
\hline X21 & Pengeluaran untuk perumahan \\
\hline X22 & $\begin{array}{l}\text { Pengeluaran untuk aneka barang dan } \\
\text { jasa }\end{array}$ \\
\hline X23 & Pengeluaran untuk biaya pendidikan \\
\hline X24 & Pengeluaran untuk biaya kesehatan \\
\hline X25 & $\begin{array}{l}\text { Pengeluaran untuk pakaian dan alas } \\
\text { kaki }\end{array}$ \\
\hline X26 & Pengeluaran untuk barang tahan lama \\
\hline X27 & Pengeluaran untuk pajak dan asuransi \\
\hline X28 & Pengeluaran untuk keperluan pesta \\
\hline
\end{tabular}

\section{Hasil dan Pembahasan}

\subsection{Kabupaten Sangihe}

Gambar 1 dan Gambar 2 adalah hasil analisis biplot pengeluaran makanan dan bukan makanan di Kabupaten Sangihe. Keragaman data yang dapat diterangkan oleh Gambar 1 adalah 64,6\% dan Gambar 2 sebesar 73,9\%. Berdasarkan nilai peubah pada suatu objek, informasi ini berguna untuk mengetahui peubah-peubah mana yang mendominasi karakteristik setiap objek. Pada Gambar 1, Kecamatan Sa90 (Tahuna) dominan (unggul) pada pengeluaran untuk tembakau dan sirih $\left(\mathrm{X}_{15}\right)$, konsumsi lainnya (dalam hal ini mie,kerupuk,makaroni,emping,dll), serta telur dan susu. Hal ini dapat diterangkan karena vektor dari ketiga peubah tersebut searah dengan objek Sa90. Kecamatan Sa91 (Tahuna Timur) dominan pada pengeluaran untuk kacang-kacangan $\left(\mathrm{X}_{17}\right)$ dan daging (X14). Kecamatan Sa41 (Tatoareng) dominan pada pengeluaran konsumsi ikan(X13), minuman alkohol $\left(X 1_{14}\right)$, buah-buahan $\left(X 1_{8}\right)$, bumbu-bumbuan $\left(X 1_{11}\right)$ dan sayur-sayuran (X16). Pada Kecamatan Sa50 (Tamako), Sa92(Tahuna Barat), Sa40(Manganitu Selatan) dan Sa80 (Manganitu) cukup dominan pada pengeluaran minyak dan lemak (X19), bahan minuman $\left(X 1_{10}\right)$ dan ubi-ubian $\left(X 1_{2}\right)$. Sedangkan pada pengeluaran bukan makanan (lihat Gambar 2), Kecamatan Sa91(Tahuna Timur) dominan pada pengeluaran untuk perumahan $\left(X 2_{1}\right)$, keperluan pesta (X28), pajak dan asuransi (X27) dan pengeluaran untuk biaya pendidikan (X23) hal ini karena vektor keempat peubah tersebut yang searah dengan objek Sa91. Kecamatan Sa41 (Tatoareng) dominan pada pengeluaran untuk aneka barang dan jasa (X22), barang tahan lama (X26), pakaian dan alas kaki (X25) serta biaya kesehatan (X24). Sedangkan Kecamatan Sa90 (Tahuna) cukup dominan pada pengeluaran untuk pajak dan asuransi (X27) dan biaya pendidikan (X23). 


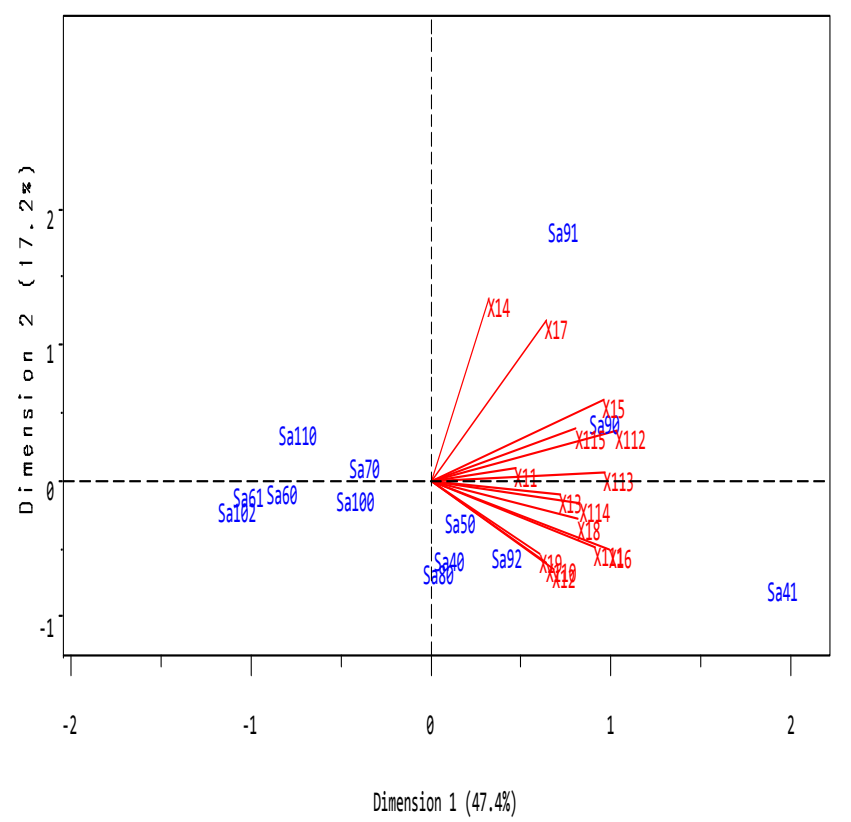

Gambar 1 - Analisis Biplot peubah X1 Sangihe

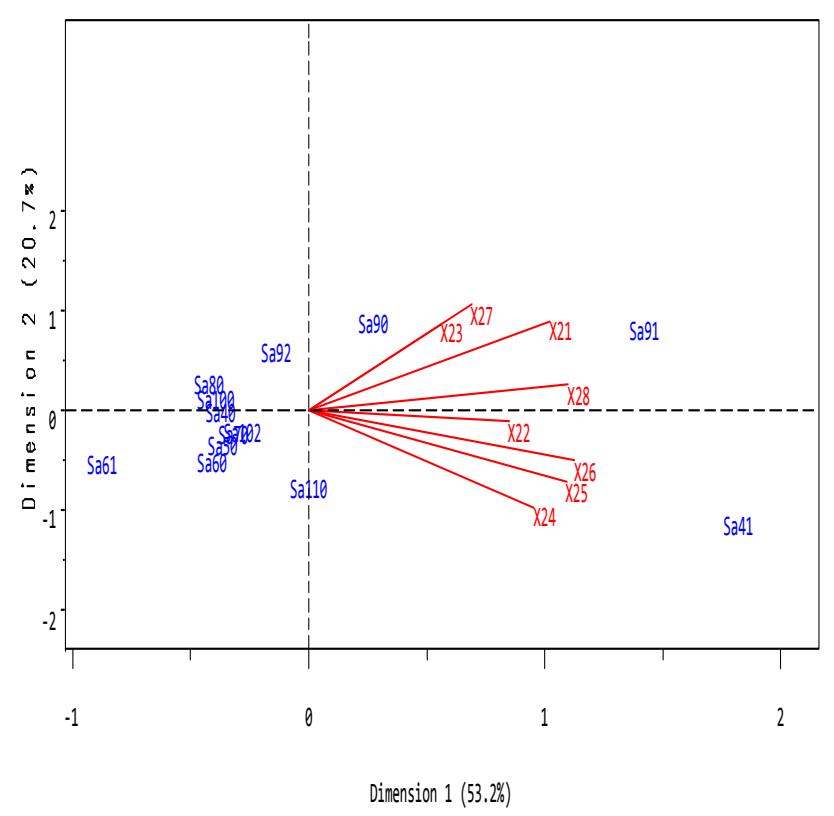

Gambar 2 - Analisis Biplot peubah X2 Sangihe

\subsection{Kabupaten Talaud}

Keragaman data yang dapat diterangkan pada analisis biplot Gambar 3 adalah 43,9\% dan Gambar 4 adalah $57,1 \%$.

Berdasarkan Gambar 3, Kecamatan Ta51(Tampa Na'mma) dan Ta23(Moronge) merupakan kecamatan yang memiliki pengeluaran yang dominan pada ubi- ubian $\left(\mathrm{X} 1_{2}\right)$ dan minuman alkohol $\left(\mathrm{X} 1_{14}\right)$. Hal ini karena kedua vektor peubah tersebut yang letaknya searah dengan objek Ta51. Pengeluaran makanan di Kecamatan Ta10(Kabaruan) didominasi oleh pengeluaran untuk minuman alkohol ( $\left.X 1_{14}\right)$. Kecamatan Ta50(Rainis) cenderung dominan pada pengeluaran untuk bumbu-bumbuan ( $\left.\mathrm{X}_{11}\right)$, minyak dan lemak (X19), bahan minuman (X110) dan pengeluaran untuk makanan dan minuman jadi (X113). Kecamatan Ta20 (Lirung) memiliki pengeluaran yang dominan pada buah-buahan (X18) dan pengeluaran untuk telur dan susu (X15). Kecamatan Ta30 (Melonguane) dan Ta60 (Essang) memiliki kemiripan karakteristik dalam pengeluaran makanan yang dominan pada pengeluaran untuk sayur-sayuran (X16) dan cukup dominan untuk konsumsi sayur-sayuran (X16), makanan dan minuman jadi $\left(X 1_{13}\right)$ juga untuk konsumsi lainnya (mie,kerupuk). Sedangkan untuk pengeluaran bukan makanan (Gambar 4), Kecamatan Ta10 (Kabaruan), Ta22 (Kalongan) dan Ta42 (Beo Selatan) memiliki kemiripan karakteristik pada pola pengeluaran bukan makanan, kecamatan-kecamatan tersebut memiliki pengeluaran yang cenderung dominan untuk keperluan pesta (X28). Sedangkan kecamatan Ta50 (Rainis) memiliki pengeluaran dominan pada pakaian dan alas kaki (X25) dan barang tahan lama (X27). Pengeluaran bukan makanan pada Kecamatan Ta20 (Lirung) dominan pada biaya kesehatan (X24), biaya pendidikan (X23), aneka barang dan jasa $\left(X 2_{2}\right)$, dan perumahan beserta fasilitas rumah tangga $\left(X 2_{1}\right)$.

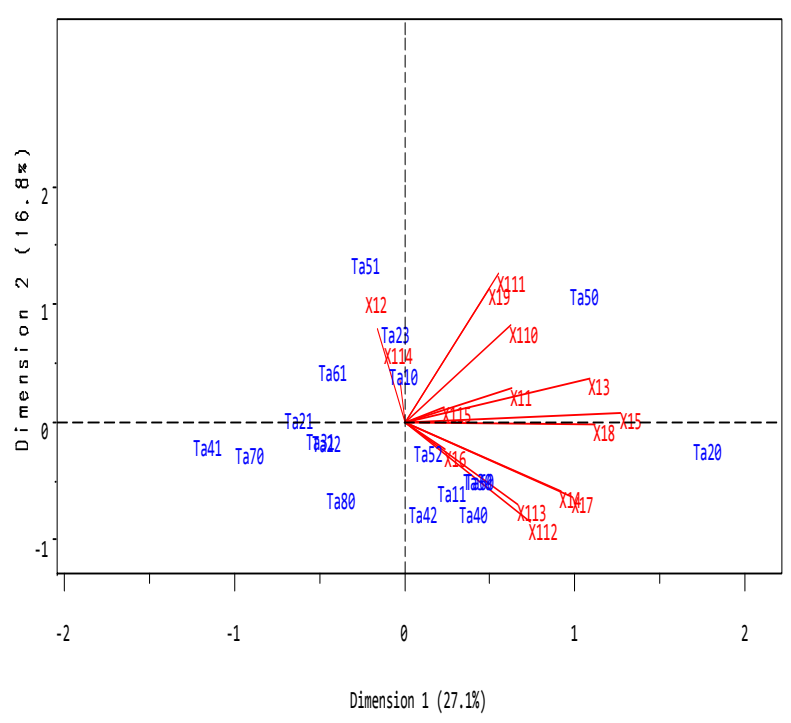

Gambar 3 - Analisis Biplot Peubah X1 Talaud

\subsection{Kabupaten Sitaro}

Keragaman data yang dapat diterangkan oleh hasil analisis biplot pada Gambar 5 adalah $64,6 \%$ dan Gambar 6 adalah 62,4\%.

Gambar 4 - Analisis Biplot Peubah X2 Talaud 


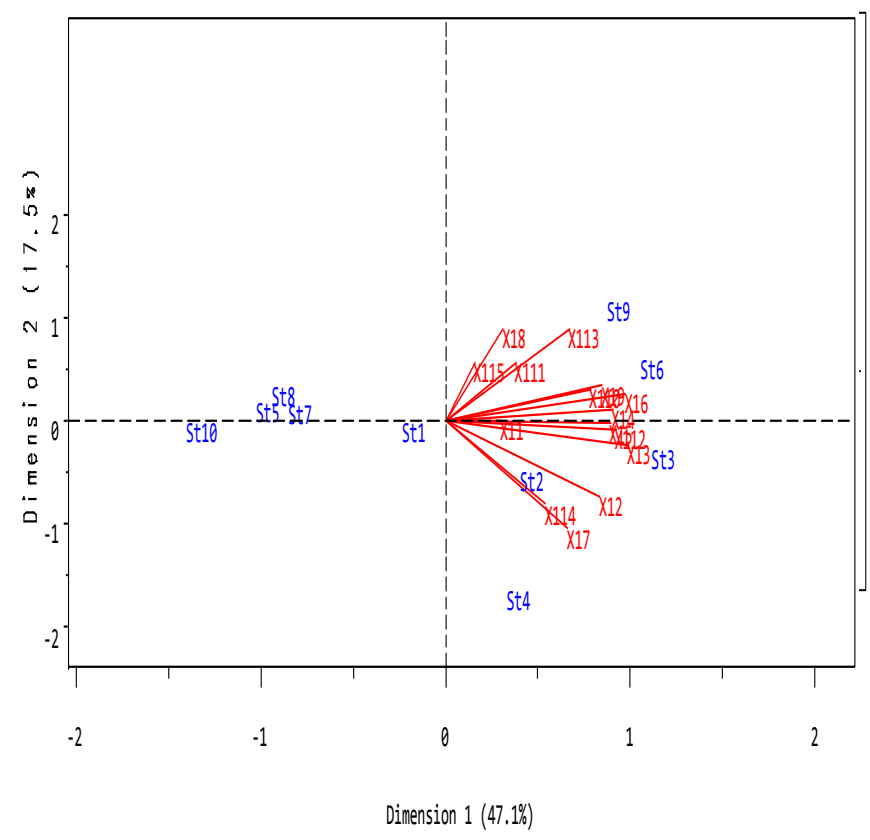

\section{Gambar 5 - Analisis Biplot peubah X1 Sitaro}

Pada Gambar 5 (plot pengeluaran makanan), Kecamatan St9 (Siau Timur) memiliki pengeluaran yang dominan terhadap konsumsi makanan dan minuman jadi $\left(X 1_{13}\right)$, bumbu-bumbuan $\left(X_{11}\right)$, buahbuahan (X18), dan pengeluaran untuk tembakau dan sirih (X115). Pengeluaran makanan pada Kecamatan St6 (Siau Timur Selatan) didominasi oleh sayursayuran (X16), minyak dan lemak (X19), serta bahan minuman $\left(X 1_{10}\right)$. Sedangkan di Kecamatan St3 (Tagulandang) memiliki dominan pengeluaran untuk ikan (X13), konsumsi lainnya (mie, kerupuk, dan lainlain) $\left(X 1_{12}\right)$, telur dan susu $\left(X 1_{5}\right)$, daging $\left(X 1_{4}\right)$, dan konsumsi padi-padian. Untuk hasil analisis biplot pengeluaran bukan makanan (Gambar 6), ditinjau dari korelasi antar peubah, peubah-peubah pada Gambar 6 saling berkorelasi positif yang ditandai dengan vektor-vektor peubah yang saling membentuk sudut lancip. Berdasarkan nilai peubah pada suatu objek, Kecamatan St6 (Siau Timur Selatan) memiliki pengeluaran yang cenderung dominan untuk biaya pendidikan (X23), barang tahan lama (X26), aneka barang dan jasa $\left(\mathrm{X}_{2}\right)$ dan pengeluaran untuk pemeliharaan rumah dan fasilitas rumah tangga $\left(X 2_{1}\right)$. Kecamatan St9 (Siau Timur) dominan pada pengeluaran untuk barang tahan lama (X26), pajak dan asuransi $(X 27)$, serta pengeluaran untuk pakaian dan alas kaki (X25).

\section{Kesimpulan}

Rata-rata pengeluaran bukan makanan di Kabupaten Sangihe, Talaud dan Sitaro cenderung lebih tinggi dibandingkan dengan pengeluaran untuk makanan.

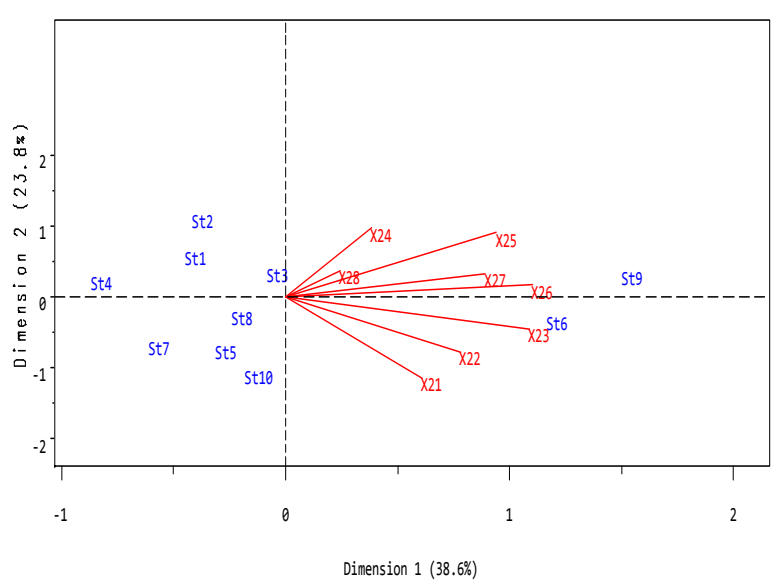

Gambar 6 - Analisis Biplot peubah X2 Sitaro

Peubah-peubah pengeluaran untuk makanan yang mendominasi karakteristik pola pengeluaran di Kabupaten Sangihe, Talaud dan Sitaro adalah pengeluaran untuk mie, kerupuk, rokok, telur, susu, kacang-kacangan, daging, ikan, minuman alkohol, buah-buahan, bumbu-bumbuan, sayur-sayuran, ubiubian, minyak, lemak, bahan minuman, makanan jadi, minuman jadi, padi-padian. Sedangkan peubahpeubah pengeluaran bukan makanan yang mendominasi karakteristik pola pengeluaran di Kabupaten Sangihe, Talaud dan Sitaro adalah pengeluaran untuk biaya pendidikan, pajak, asuransi, pemeliharaan rumah, keperluan pesta, aneka barang dan jasa, barang tahan lama, pakaian dan alas kaki serta biaya kesehatan.

\section{Daftar Pustaka}

Anonim. 2010. Profil Kemiskinan Tahun 2010. BPS Provinsi Sulawesi Utara. Manado

Anonim. 2011a. Provinsi Sulawesi Utara dalam Angka 2011. BPS Provinsi Sulawesi Utara. Manado

Anonim. 2011b. Pengeluaran Konsumsi Penduduk Indonesia 2011. BPS. Jakarta

Anonim. 2011c. Berita Resmi Statistik No. 42/07/71/Th.V/1 Juli 2011. http://www.bps.go.id. Diakses 10 April 2012 pukul 18.30 WITA

Jolliffe, I.T. 1986. Principal Component Analysis. Springer-Verlag. New York.

Mattjik, A.A., M. Sumertajaya, H. Wijayanto, Indahwati, A. Kurnia, B. Sartono. 2004. Modul Teori Pelatihan Analisis Multivariat. Departemen Statistika FMIPA IPB. Bogor.

Mayasari, N.I. 2010. Analisis Profil Sosial Ekonomi Rumah Tangga Berdasarkan Pola Pengeluaran 
antara Perdesaan dan Perkotaan di Propinsi Jawa Timur. FMIPA ITS. Surabaya
Rencher, A.R. 2002. Methods of Multivariate Analysis Second Edition. John Wiley \& Sons, Inc. New York 